\title{
The effect of oral digoxin on sodium excretion, renin- angiotensin-aldosterone system and blood pressure in normotensive subjects
}

\author{
Francesco P. Cappuccio, Nirmala D. Markandu, Giuseppe A. Sagnella and Graham \\ A. MacGregor
}

Blood Pressure Unit, Department of Medicine, Charing Cross \& Westminster Medical School, London W6 8RF, UK.

\begin{abstract}
Summary: The effect of digoxin ( $0.25 \mathrm{mg}$ t.d.s.) given orally for 5 days, on sodium excretion, plasma renin activity, plasma aldosterone and blood pressure has been studied in 6 normotensive subjects, on a constant sodium intake. Average serum digoxin level measured in 5 subjects on the 5th day of treatment was in the upper range of the therapeutic level (1.92 $\pm 0.3 \mathrm{nmol} / \mathrm{l})$. Red cell sodium content increased from $9.75 \pm 1.2 \mathrm{mmol} / 1$ of cells in the control period to $15.3 \pm 1.7 \mathrm{mmol} / \mathrm{l}$ of cells on the 5 th day of digoxin treatment when measured in 4 of the 6 subjects. In spite of this evidence of inhibition of the red cell sodium pump, there was no detectable change in sodium excretion, blood pressure, plasma renin activity and aldosterone.
\end{abstract}

\section{Introduction}

Digoxin and ouabain are known to cause a natriuresis when given intra-arterially or intravenously in animals and in men (Farber et al., 1951; Hyman et al., 1956; Hook, 1969), to increase vascular reactivity of isolated arterial preparations (Flaim \& DiPette, 1979; Mikkelsen et al., 1979), to increase sympathetic activity in vitro (Toda, 1980; Aarhus et al., 1983) and to cause inhibition of renin secretion both in vitro (Churchill, 1979) and in vivo (Covit et al., 1983). We, therefore, investigated the effects of digoxin given orally for 5 days to normotensive subjects, on sodium excretion, blood pressure, plasma renin activity and aldosterone.

\section{Patients and methods}

Six healthy, normotensive male volunteers were studied over 3 weeks as outpatients after a few days of observation in the blood pressure unit; the mean age was $21.3 \pm 0.33$ years. The average supine blood pressure was $111 / 65 \pm 5 / 5 \mathrm{~mm} \mathrm{Hg}$. During the whole study subjects were on a fixed normal sodium intake of $120 \mathrm{mmol} /$ day and potassium intake of $80 \mathrm{mmol} /$ day. All food and drink was provided by the metabolic kitchen. After a 1 week control period, subjects were given an oral loading dose of digoxin (Lanoxin) $0.50 \mathrm{mg}$ in the morning and thereafter $0.25 \mathrm{mg}$ t.d.s.

Correspondence: G.A. MacGregor M.A., F.R.C.P. Accepted: 10 October 1985 for 5 days; a further week's control period was continued on a fixed sodium intake after stopping digoxin. Informed consent was obtained from each subject and the study protocol was approved by Charing Cross Hospital Ethical Committee. During the study, subjects were seen in the Blood Pressure Unit every day for blood pressure, pulse rate and weight measurements. All subjects were told not to take vigorous exercise. Daily 24 hour urines were collected for the measurement of sodium and potassium excretion. Blood was taken during each period for measurement of electrolytes, creatinine, urea, plasma renin activity and aldosterone. In the first week and on the 5th day of the experimental period on digoxin, red blood cell sodium content was measured in 4 of the 6 subjects; serum digoxin levels were measured at the end of the experimental period in 5 subjects. Subjects were seen daily between 10.00 hours and 12.00 hours by the same nurse, in the same room. Blood pressure was measured in the same arm by nurses using semi-automatic ultrasound sphygmomanometers (Arteriosonde) (George et al., 1975) with attached recorders. The measurements were therefore free from observer bias. Supine and standing blood pressures were the means of 5 readings taken at 1-2 minute intervals with the subjects in the corresponding position; supine pressures were measured before standing pressures. Pulse rate was measured on a Cambridge 3048 pulse monitor. Subjects were carefully instructed on how to collect 24 hour 
specimens of urine. Blood samples were taken without stasis after the subject had been sitting upright for 10 minutes. Plasma renin activity (Roulston \& MacGregor, 1978) and aldosterone (James \& Wilson, 1976) were measured by radioimmunoassay. Serum digoxin was measured by radioimmunoassay using a kit with ${ }^{125}$ I-digoxin (The Radiochemical Centre, Amersham, Buckinghamshire). All results are reported as means \pm s.e.m. Because of the small number of subjects Wilcoxon's rank sum test was carried out for the statistical evaluation as described by Colton (1974).

\section{Results}

Average serum digoxin level measured on the 5th day of oral treatment in 5 subjects was in the upper range of the therapeutic levels showing a mean value of $1.92 \pm 0.33 \mathrm{nmol} / 1$ and red cell sodium content, measured in 4 subjects, increased from $9.75 \pm 1.21$ to $15.30 \pm 1.70 \mathrm{mmol} / 1$ of cells (Table I).

During the one-week control period before digoxin was given, mean 24 hour urinary sodium excretion was $117 \pm 6 \mathrm{mmol}$. There was a small but non-significant increase in sodium excretion on the first day of digitalization ( $137 \pm 10 \mathrm{mmol}$ of sodium/24 hour). However, during the 5 days of digoxin treatment there was no detectable change in sodium balance, mean 24 hour urinary sodium excretion being $118 \pm 7 \mathrm{mmol}$ (Figure 1). In the week following digoxin, mean 24 hour urinary sodium was $126 \pm 8 \mathrm{mmol}$. Digoxin treatment did not produce any significant change in potassium excretion; mean 24 hour urinary potassium excretion before digoxin was $76.9 \pm 3.5 \mathrm{mmol}$, $83.1 \pm 5 \mathrm{mmol}$ during digoxin treatment and $76.8 \pm 5 \mathrm{mmol}$ following digoxin (Figure 1). Plasma renin activity before treatment was $2.33 \pm 0.65 \mathrm{ng} / \mathrm{ml} /$ hour, on the 5 th day of digoxin was $2.84 \pm 0.47 \mathrm{ng} / \mathrm{ml} /$ hour and on the 3rd day of the control week after stopping digoxin was $3.04 \pm 0.64 \mathrm{ng} / \mathrm{ml} /$ hour. Plasma aldosterone did not change during the study: before treatment it was $486 \pm 89 \mathrm{pmol} / 1$, on the 5 th day of digoxin treatment $451 \pm 74 \mathrm{pmol} / 1$ and on the $3 \mathrm{rd}$ day of the control period after digoxin $397 \pm 62 \mathrm{pmol} / 1$.

Supine and standing blood pressures which were measured daily throughout the study showed no significant changes (Figure 2). On the day before the administration of digoxin average supine blood pressure was $117 / 63 \pm 4 / 2 \mathrm{~mm} \mathrm{Hg}$, by the end of the digoxin treatment it was $119 / 67 \pm 6 / 3 \mathrm{~mm} \mathrm{Hg}$ and one week after stopping digoxin it was 116/62 $\pm 5 /$ $4 \mathrm{~mm} \mathrm{Hg}$. Heart rate gradually fell during the study from $71 \pm 5$ before the administration of digoxin to $60 \pm 4$ beats/minute on the 4th day of digoxin treatment. On the third day after stopping digoxin heart rate was $71 \pm 4$ beats/minute and, for the group,
Table I Serum digoxin levels on the 5th day and red cells sodium content measured before and after 5 days of oral treatment with digoxin in normotensive subjects (n.d. $=$ not determined).

\begin{tabular}{|c|c|c|c|}
\hline \multirow{3}{*}{$\begin{array}{l}\text { Subject } \\
\text { number }\end{array}$} & \multirow{3}{*}{$\begin{array}{c}\begin{array}{c}\text { Serum digoxin } \\
(\mathrm{nmol} / \mathrm{l})\end{array} \\
2.7\end{array}$} & \multicolumn{2}{|c|}{ Red cells sodium } \\
\hline & & \multicolumn{2}{|c|}{$\begin{array}{c}\text { Pre-treatment } 5 \text { th day } \\
(\mathrm{mmol} / \mathrm{l} \text { cells })\end{array}$} \\
\hline & & 7.8 & 14.5 \\
\hline 2 & 2.2 & n.d. & 15.5 \\
\hline 3 & 2.3 & 9.1 & 13.2 \\
\hline 4 & 1.6 & 8.8 & 11.6 \\
\hline 5 & n.d. & 13.3 & 21.9 \\
\hline 6 & 0.8 & n.d. & n.d. \\
\hline
\end{tabular}

remained steady thereafter.

No changes in body weight, plasma sodium and potassium, urea and creatinine were observed during the study. One subject on the last day of digoxin treatment complained of some nausea and yellow vision. There were no other reported side effects and all subjects completed the study.

\section{Discussion}

Several studies have demonstrated the extracardiaco effects of infused glycosides (Farber et al., 1951:0 Hyman et al., 1956; Hook, 1969; Covit et al., 1983;

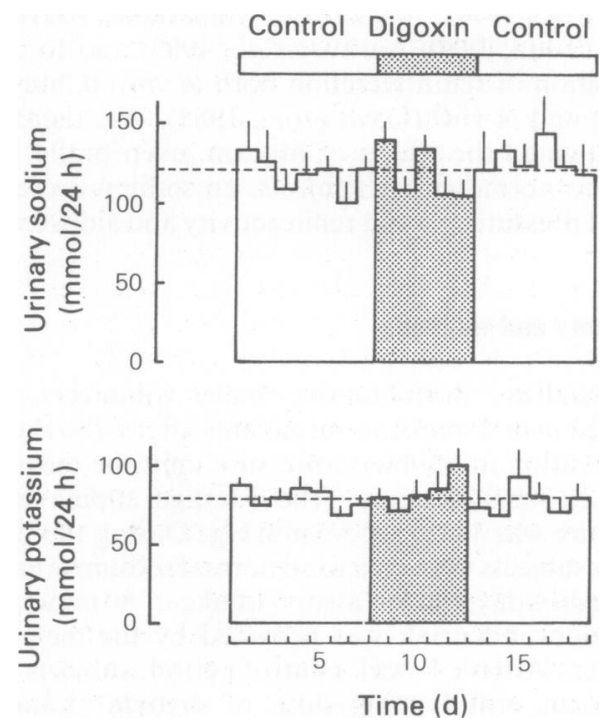

Figure 1 Average daily urinary sodium and potassium excretion ( \pm s.e.m.) in the six normal subjects 7 days before, 5 days of and 7 days after digoxin treatment. Dotted lines represent the estimated daily intake. 


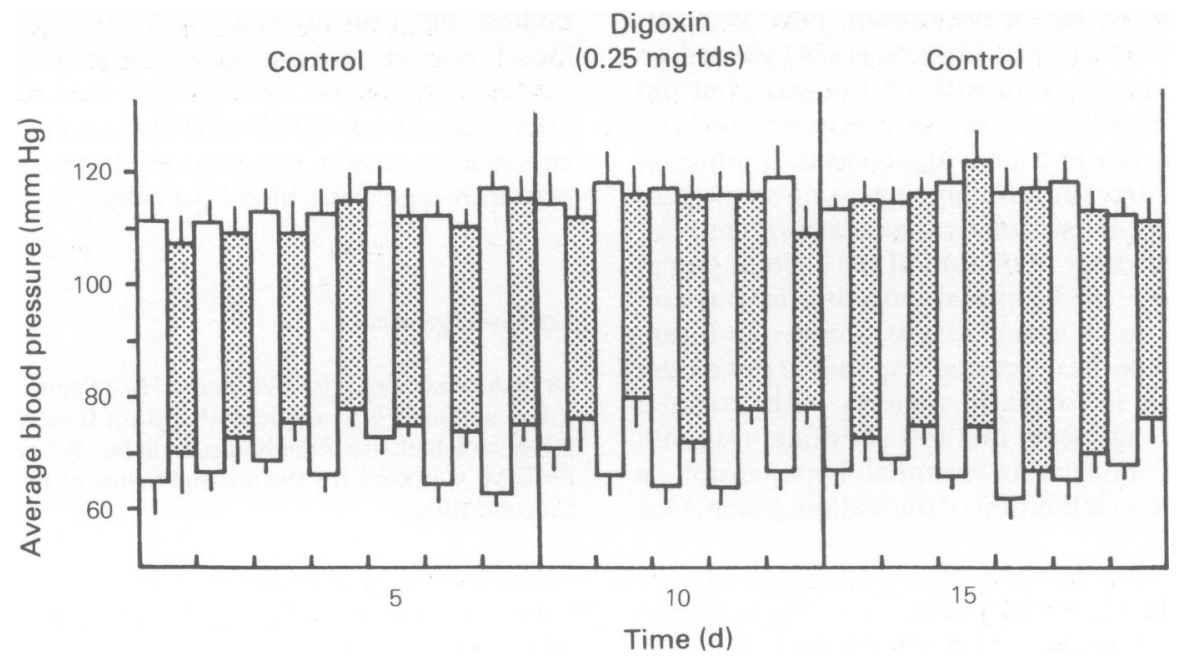

Figure 2 Average daily supine ( $\square$ ) and standing (罒) systolic and diastolic blood pressure ( \pm s.e.m.) in the six normal subjects 7 days before, 5 days of and 7 days after digoxin treatment.

Strickler \& Kessler, 1961; Mason \& Braunwald, 1964; Williams et al., 1958; Robinson et al., 1983), but there is little information on the extracardiac effects of digitalis glycosides given orally to normal man.

In our study, a high dose of digoxin given orally for 5 days to normotensive subjects did not change sodium excretion. Furthermore, there was no detectable change in plasma renin activity, plasma aldosterone or blood pressure, in spite of the fact that during the study, on average, serum digoxin levels after 5 days of treatment were in the therapeutic range and there was a marked increase in red cell sodium content by the 5 th day of digoxin treatment, presumably indicating inhibition of $\mathrm{Na}^{+}-\mathrm{K}^{+}$-ATPase in these red cells (Gill \& Solomon, 1959; Glynn, 1964; Morgan et al., 1980).

The natriuretic effects of glycosides have only been demonstrated in animals and man following intraarterial or intravenous injection. Hook (1969) infused ouabain at a high dose in dog's renal arteries and measured either sodium excretion in vivo or $\mathrm{Na}^{+}-\mathrm{K}^{+}$. ATPase activity in slices of kidney in vitro. He found a dose-related natriuresis and, concomitantly, a doserelated depression of $\mathrm{Na}^{+}-\mathrm{K}^{+}$-ATPase obtained from the renal cortex, supporting the view that inhibition of renal $\mathrm{Na}^{+}-\mathrm{K}^{+}$-ATPase could be responsible for the natriuretic response that was seen.

Hyman et al. (1956) injected digoxin directly into one renal artery of a dog and observed an increase in water and sodium excretion from the injected kidney. Strickler \& Kessler (1961) injected several cardiac glycosides into one renal artery of dogs, but found that only certain cardiac glycosides caused a natriuresis. They suggested that the beta-lactone ring was essential for the natriuretic response. In man, Farber et al. (1951) demonstrated a prompt and considerable natriuresis following intravenous digoxin infusion in patients with congestive heart failure and suggested that digoxin might act in heart failure by its effect on renal tubular sodium excretion. In normotensive subjects the results were not so clearcut and there appeared to be no significant increase in sodium excretion. More recently, Guthrie (1984) showed no change in urinary sodium excretion following oral digoxin treatment for 4 days in normotensive subjects although, unlike our study, sodium intake was not controlled and it is difficult therefore to draw definite conclusions.

In our study cumulative urinary sodium excretion during the 5 days of digoxin treatment did not differ significantly from the sodium excretion before and after digoxin. Digoxin is likely to have been still present in the control period after stopping the drug as it has a reported mean half-life of approximately 40 hours (Kelman et al., 1980). Nevertheless this would seem unlikely to affect our results as neither urinary sodium, potassium or blood pressure showed any significant change throughout the entire study.

Ouabain is known in vitro to inhibit renin release (Churchill, 1979) and Covit et al. (1983) have recently demonstrated an acute inhibitory effect of digoxin on plasma renin activity when given intravenously in patients with congestive heart failure. However, Guthrie (1984) in his study with oral digoxin showed, like us, no changes in plasma renin activity or plasma aldosterone.

Intravenous ouabain infusion in normotensive subjects causes an increase in peripheral resistance and 
blood pressure (Mason \& Braunwald, 1964; Williams et al., 1958). Furthermore, Guthrie (1984) showed no change in blood pressure with oral digoxin but did show an increased blood pressure response to both noradrenaline infusion and angiotensin II infusion after 4 days of digoxin, strongly suggesting an increase in the sensitivity of arteriolar vascular smooth muscle cells to agonists after inhibition of the sodium pump. Robinson et al. (1983) infused intra-arterial ouabain into the forearm of normotensive subjects and were able to reproduce the depressed response to potassium infusion which is found in patients with essential hypertension, suggesting that this abnormal response to potassium infusion in essential hypertension is likely to be due to inhibition of the sodium pump. Our

\section{References}

AARHUS, L.L., SHEPHERD, J.T., TYCE, G.M., VERBEUREN, T.J. \& VANHOUTTE, P.M. (1983). Contractions of canine vascular smooth muscle cells caused by ouabain are due to release of norepinephrine from adrenergic nerve endings. Circulation Research, 52, 501.

CHURCHILL, P.C. (1979). Possible mechanism of the inhibitory effect of ouabain on renin secretion from rat renal cortical slices. Journal of Physiology, 294, 123.

COLTON, T. (1974). In Statistics in Medicine. Little, Brown and Company: Boston, Massachussetts.

COVIT, A.B., SCHAER, G.L., SEALEY, J.E., LARAGH, J.H. \& CODY, R.J. (1983). Suppression of the renin angiotensin system by intravenous digoxin in chronic congestive heart failure. American Journal of Medicine, 75, 445.

FARBER, S.J., ALEXANDER, J.D., PELLEGRINO, E.D. \& EARLE, D.P. (1951). The effect of intravenously administered digoxin on water and electrolyte excretion and on renal functions. Circulation, 4, 378.

FLAIM, S.F. \& DIPETTE, D.J. (1979). Digoxin-norepinephrine response and calcium blocker effects in vascular smooth muscle. American Journal of Physiology, 236, H613.

GEORGE, C.F., LEWIS. P.J. \& PETRIE, A. (1975). Clinical experience with the use of an ultrasound sphygmomanometer. British Heart Journal, 37, 804.

GILL, T.J. \& SOLOMON, A.K. (1959). Effect of ouabain on sodium flux in human red cells. Nature, 183, 1127.

GLYNN, I.M. (1964). The action of cardiac glycosides on ion movements. Pharmacological Reviews, 16, 381.

GUTHRIE, G.P., JR. (1984). Effects of digoxin on responsiveness to the pressor actions of angiotensin and norepinephrine in man. Journal of Clinical Endocrinology and Metabolism, 58, 76.

HOOK, J.B. (1969). A positive correlation between natriuresis and inhibition of renal $\mathrm{Na}-\mathrm{K}$-adenosine triphosphatase by ouabain. Proceedings of the Society of Experimental Biology and Medicine, 131, 731.

HYMAN, A.L., JAQUES, W.E. \& HYMAN, E.S. (1956). Observation on the direct effect of digoxin on renal excretion of sodium and water. American Heart Journal, 52, 592.

JAMES, V.H.T. \& WILSON, G.A. (1976). Determination of finding that oral digoxin for 5 days does not alter blood pressure does not, therefore, exclude the role of cardiac glycosides in altering the reactivity of arteriolar smooth muscle cells or the potential effect of endogenous sodium transport inhibitors over a longer period in regulating blood pressure.

\section{Acknowledgements}

Dr G.A. MacGregor is a Wellcome Trust Senior Lecturer. Dr F.P. Cappuccio is a recipient of a grant from the Ministero Pubblica Istruzione Repubblica Italiana. We are grateful to Dr E.M. Clarkson for the measurements of red cell sodium concentration. aldosterone in biological fluids. In Assay of Drugs and Other Trace Compounds in Biological Fluids - Methodological Development in Biochemistry, vol. 5, Reid, E. (ed). pp.149-158. Elsevier: Amsterdam.

KELMAN, A.W., SUMNER, D.J., LONSDALE, M., LAWRENCE, J.R. \& WHITING, B. (1980). Comparative pharmacokinetics and pharmacodynamics of cardiac glycosides. British Journal of Clinical Pharmacology, 10, 135.

MASON, D.T. \& BRAUNWALD, E. (1964). Studies on digitalis, $\mathrm{X}$, Effects of ouabain on forearm vascular resistance ando venous tone in normal subjects and in patients in heart failure. Journal of Clinical Investigation, 43, 532.

MIKKELSEN, E., ANDERSSON, K.E. \& LEDERBALLE PEDERSEN, O. (1979). Effects of digoxin on isolated human mesenteric vessels. Acta Pharmacologica et Toxicologica, 45, 25.

MORGAN, D.B., CUMBERBATCH, M., COLM, S., SCOTT, D., GUNASUNTHARAM, T., DAVIDSON, C. \& CHAPMAN, C. (1980). The erythrocyte sodium and potassium in patients treated with digoxin. British Journal of Clinical Pharmacology, 10, 127.

ROBINSON, G.F., PHILlIPS, R.J.W., WILSON, P.N. \& CHIODINI, P.L. (1983). Effect of local infusion of ouabain on human forearm vascular resistance and on response to potassium, verapamil and sodium nitroprusside. Journal of Hypertension 1, 165.

ROULSTON, J.E. \& MACGREGOR, G.A. (1978). Measurement of plasma renin activity by radioimmunoassay after prolonged cold storage. Clinica Chimica Acta, 88, 45.

STRICKLER, J.C. \& KESSLER, R.H. (1961). Direct renal action of some digitalis steroids. Journal of Clinical Investigation, 40, 311.

TODA, N. (1980). Mechanisms of ouabain-induced arterial muscle contraction. American Journal of Physiology, 239, H119.

WILLIAMS, M.H., JR, ZOHMAN, L.R. \& RETNER, A.C. (1958). Hemodynamic effects of cardiac glycosides on normal human subjects during rest and exercise. Journal of Applied Physiology, 13, 417. 